\title{
KONSEP KERUKUNAN DALAM KOMUNIKASI PEMBANGUNAN AGAMA DI SOSIAL MEDIA
}

\author{
Arina Rahmatika
}

Email:arina.eljawie@gmail.com

\begin{abstract}
Information and communication technology is growing rapidly in Indonesia and has become part of the community, one of which is social media. The social presence of the media as a public space becomes a new style of communication even in creating inter-religious communication spaces in the community. This certainly will affect the level of harmony among religious people in Indonesia. Through communication of the development of social media as a medium of communication, dissemination, it is hoped that it can build a strengthening of religious harmony through various elements of society, both individual and institutional.
\end{abstract}

Keywords: Harmony, Religion, Social Media. 


\begin{abstract}
Abstrak
Teknologi informasi dan komunikasi semakin berkembang pesat di Indonesia dan telah menjadi bagian dari masyarakat, salahsatunya adalah sosial media. Kehadiran sosial media sebagai ruang publikmenjadigaya baru dalamberkomunikasi bahkan dalam menciptakan ruang komunikasi antar agama di masyarakat. Hal ini tentunya akan berpengaruh terhadap tingkat kerukunan umat beragama di Indonesia. Melalui komunikasi pembangunan media sosial sebagai media sosialisasi komunikasi yang diharapkan dapat membangun penguatan kerukunan agamamelalui berbagai elemen masyarakat, baik individu ataupun kelembagaan.
\end{abstract}

Kata kunci: Kerukunan, Agama, Sosial Media

\section{A. Pendahuluan}

Perkembangan

teknologi

informasi dan komunikasi telah berkembang sangat pesat. Hal itu terlihat dari adanya sarana baru yang digunakan untuk berkomunikasi dan mengakses informasi dan peristiwa dibelahan dunia lain dalam satu waktu. Kemajuan teknologi ini akhirnya mampu membawa manusia berkomunikasi melewati batas dan waktu serta tanpa ada rahasia yang bisa ditutupi.

Salahsatu bentuk perkembangan teknologi dan informasi adalah adanya sosial media. Bahkan kehadiran sosial media semakin berkembang jumlah penggunanya dari hari ke hari memberikan fakta menarik betapa kekuatan sosial media bagi kehidupan manusia. Media sosial pun semakin beragam seperti twitter, facebook, Instagram dan lain-lain.

Data lembaga We Are Socialmenunjukkan bahwa di Indonesia sendiri ada sekitar 62 juta orang yang terdaftar serta memiliki akun di media sosial facebook dan dengan rata-rata pengguna menghabiskan waktu hampir 3 jam untuk terkoneksi dan berselancar di media sosial. Sebagian besar mengakses dengan menggunakan perangkat handphone dan PC.

Sejak kehadiran sosial mediatercipta gaya baru dalam berkomunikasi sehari-hari. Jika dulu komunikasi langsung secara tatap muka, sekarang hal itu mulai jarang terjadi dan bergeser menjadi komunikasi gaya virtual yang lebih mengedepankan kecanggihan teknologi.Bahkan sosial media 
menjadikebutuhan primer darisetiap orang dan tidak heran jika"social media is an information content created by people using highly accessible and scalable publishing technologies". Tidak hanya itu, intensitas menggunakan sosial media yang tinggipun akhirnya menjadi candu karena keasyikan yang ditawarkan walaupun idealnya media sosial merupakan sebuah teknologi yang dapat memudahkan manusia untuk mencapai sesuatu yang diinginkan secara efisien dalam waktu singkat.

Disisi lain media sosial menjadikan masyarakat memiliki sifat-sifat eksklusif dan individualis serta sikap fanatisme terhadap suku, ras, etnis, dan agama.Hal itu dikarenakan revolusi teknologi dan informasi yang telah membuat intensitas komunikasi dan interaksi antar manusia menjadi semakin kaburdanhilangakan batas ruang dan waktu.Kondisi demikian membuat agama menempati posisi strategis untuk menghindari masyarakat yang salah arah.

Indonesia yang menganut system Pancasila dalam sila pertama menyebutkan bahwa Ketuhanan Yang Maha Esa, menjadi symbol bahwa agama hadir di Indonesia. Agama yang diakui oleh pemerintahIndonesia antara lain yaitu Islam, Kristen, Katolik, Hindu, Budha dan Konghucu. Dari 6 agama yang dianut warga Indonesia, FKUB pada tahun 2016 mencatat indeks kerukunan umat agama adalah $75,47 \%$. Hal ini merupakan kondisi ideal bagi terciptanya terciptanya pluralitas agama, namun keanekaragaman yang terjadi di Indonesiamengandungjugaberbagai kerawanan konflik kepentingan. ${ }^{1}$

Terlebih dengan adanya media sosialyangturutsertadalambeberapa kasus agama. Seperti moslem cyber army (MCA) yang menyebarkan berita bohong dan ujaran kebencian di media sosial. Salah satu berita hoaks yang disebarkan adalah berita mengenai kasus penyerangan 40 ulama. MCA sendiriadalah organisasi tanpa bentuk di dunia maya. Anggota MCA bisa mencapai ribuan yang terbuka bagi seluruh penggun sosial media. Tidak hanya itu, mereka menggunakan hate speech, isu SARA sebagai konten yang disebarkan.

Moslem cyber army merupakan salah satu dampak apabila pengetahuan manusia akan kehidupan keagamaan tidak disertai pula dengan kesadaran akan kehidupan beragama itu sendiri. Akibatnya, dalam kehidupannya tidak mampu mencapai titik keseimbangan (titik equilibrium) sebagai landasan spiritual, moral

1 Nur Ahmad, Pluralitas Agama: Kerukunan Dalam Keragaman, (Jakarta: Kompas,2001), 49. 
dan etika, sehingga menjadi pemicu konflik dan kerusuhan yang bernuansa agama melalui media sosial. Ada berbagai macam pemicu konflik antar agama di media sosial lainnya yang mungkin saja terjadi karenaagama sebagai sistem nilai tidak dipahami dan diamalkan oleh setiap individu, keluarga, masyarakat dan pemerintah sehingga tidak memiliki daya tahan yang memadai untuk menanggulanginya.

Oleh karena itu, komunikasi pembangunan agama hadir untuk menciptakan kerukunan dan keutuhan sebuah bangsa untuk melakukan kritik dan redefinisi ulang terhadap agama dan peran sosialnya. Komunikasi pembangunan agama mencoba untuk memberikan pengertian mengenai suatu perbedaan yang merupakan sunnatullah, sehingga nantinya terciptanya kerukunan antar umat beragama di sosial media.

\section{B. Konsep Kerukunan}

Indonesia dengan enam agama yang diakui oleh negara merupakan salah satu tanda bahwa masyarakat Indonesia adalah masyarakat yang plural.Keberagaman inilah yang bisa menjadi potensi konflik, yang justru mengganggu proses pembangunan itu sendiri. Sejarah terjadinya konflik dalam hidup manusia di berbagai tempat di dunia, memberikan pelajaran bahwa kenyataannya banyak di antara konflik tersebut membawa identitas agama maupun beberagamaan oleh masing-masing kelompok, yang ingin menunjukkan identitas agama tertentu.

Padahal masing-masing agama memberikan petunjuk agar kehidupan harmonis tanpa adanya konflik dalam setiap kegiatan hidup manusia. Konflik yang diwarnai dengan kekerasan akan berdampak pada ketidaktenteraman masyarakat bukan merupakan perintah agama manapun karena setiap agama mengajarkanuntuksenantiasatolong menolong sebagai symbol ajaran bersosialisasi di dalam masyarakat. ${ }^{2}$

Oleh karena itu masyarakat perlu mengembangkan terciptanya suasana rukun agar terhindar dari konflik agama. Rukun menggambarkan suasana yang menujukkan adanya pluralitas namun satu sama lain tidak berbenturan dan bertentangan walaupun berbeda, sehingga ada usaha untuk mengkombinasikan dan saling beradaptasi satu sama lain untuk membentuk satu keseluruhan yang sejalan dan saling menunjang dengan tidak menghilangkan ciri unsur utama dari yang lama.

2 Ismail, Faishal, Dinamika Kerukunan Antarumat Beragama,(Bandung:PT. Remaja Rosdakarya,2014). 
Kerukunan umat beragama adalah proses dan suasana kehidupan beragama dari umat dan pemeluk agama yang plural yang serasi dalam kehidupan bangsa, dimana agama-agama yang berbeda dapat diamalkan oleh pemeluknya tanpa berbenturan satu dengan yang lainnya. ${ }^{3}$ Rukun sendiri memuat tiga karakter, yaitu: ${ }^{4}$

1. Presupposes dan preserves he diversty of the object

2. Its components while retaining their individuality form a new and more complex

3. Which has been challenged by relatively modern development in music

Nilai kerukunan dalam Islam sendiri telah Nabi Muhammad contohkan dalam menyusun Piagam Madinah pada tahun $622 \mathrm{M}$, khususnya menyangkut semangat dan strateginya dalam mengatur kerukunan hidup beragama. Dari Piagam Mandinah tersebut, Rasulullah telah menceritakan kepada dunia bagaimana petunjuk kerukunan antar umat beragama dilakukan dalam realitas sejarah. ${ }^{5}$

3 Ridwan Lubis, Meretas Wawasan Dan Praksis Kerukunan Umat Beragama Di Indonesia Dalam Bingkai Masyarakat Kultural, (Jakarta: Puslitbang Kehidupan Beragama, 2005), 61.

4 Ibid., 61

5 Syahrin Harahap, Teologi Kerukunan, (Jakarta: Prenada, 2011), 36
Dari piagam Madinah mengajarkan kerukunan hidup umat beragama. Dalam Piagam Madinah ada pengakuan terhadap perbedaan antara sesama manusia dalam perbedaan jenis kelamin, warna kulit (ras), sifat pembawaan, bakat, kekuasaan, agama dan keyakinan, keterampilan, kekuatan fisik dan kemampuan intelektual, kedudukan sosial, tingkat ekonomi, tingkat pendidikan dan sebagainya, namun sebagai manusia tetap diakui sama dan memiliki hak serta kewajiban yang sama. Perbedaan-perbedaan yang nyata ada di antara sesama manusia tidak dijadikan alasan untuk saling membedakan satu sama lain di antara mereka. Adanya perbedaan justru bertujuan agar mereka dapat saling mengenal. Semua itu adalah prinsip persamaan yang terdapat dalam Piagam Madinah, yaitu prinsip persamaan unsur kemanusiaan yang menyatakan bahwa seluruh penduduk Madinah adalah umat yang satu atau umat-umat yang mempunyai status yang sama dalam kehidupan sosial (Pasal 25-35).

Walaupun demikian peranan agama tetap diakui dalam menentukansetiapaspeklingkungan. Tanpa agama manusia tidak akan bisa hidup lebih sempurna. Hal itu berkaitan secara mendasar dalam hakikat kehidupan manusia, bahwa ada sesuatu yang sangat alami pada 
diri manusia yang sering disebut naluri atau fitrah untuk beragama.

\section{Komunikasi Pembangunan Agama}

Komunikasi pembangunan agama merupakan suatu komunikasi yang dilakukan untuk melaksanakan rencana pembangunan dalam bidang agama. ${ }^{6} \quad$ Pembangunan agama sebagai bagian dari pembangunan nasional merupakan salah satu pengamalan Pancasila pasal pertama yaitu Ketuhanan Yang Maha Esa, yang bertujuan untuk meningkatkan kesejahteraan rakyat melalui peningkatan kualitas pelayanan dan pemahaman agama serta kehidupan beragama. Selain itu, pembangunan agama juga mencakup peningkatan kerukunan hidup umat beragama, yang mendukung peningkatan saling percaya dan harmonisasi antarkelompok masyarakat. Oleh karena itu, komunikasi pembanguna agama merupakan suatu bentuk komunikasi yang penting untuk terbentuknya kerukunan antar masyarakat di Indonesia dan agama bisa menjadi landasan moral dan etika dalam bermasyarakat, berbangsa dan bernegara.

6 Hasan Sazali. Penguatan Toleransi Agama dalam Komunikasi Pembangunan Agama Studi Pemerintah Kota Bogor dan Yogyakarta.Disertasi, (Yogyakarta: Sekolah Pascasarjana UGM, 2015). 115
Untuk menunjang hal tersebut, pembangunan agama telah mencetuskan berbagai macam bentuk regulasi yang tujuannya untuk membangun kesejahteraan masyarakat dalam kehidupan keberagamaan agama. Bentuk regulasi ini secara jelas dinyatakan dalam Undang Undang No. 17 Tahun 2007 tentang Rencana Pembangunan Jangka Panjang Nasional Tahun 20052025, bahwa Pembangunan agama diarahkan untuk memantapkan fungsi dan peran agama sebagai landasan moral dan etika dalam pembangunan, membina akhlak mulia, memupuk etos kerja, menghargai prestasi, dan menjadi kekuatan pendorong guna mencapai kemajuan dalam pembangunan. Selain itu, pembangunan agama diarahkan juga untuk meningkatkan kerukunan hidup umat beragama dengan meningkatkan rasa saling percaya dan harmonisasi antar kelompok masyarakat sehingga tercipta suasana kehidupan masyarakat yang penuh toleransi, tenggang rasa, dan harmonis. ${ }^{7}$

Dari regulasi tersebut, pembangunan bidang agama melalui pembinaan kerukunan hidup umat beragama telah berhasil ikut serta meredakan konflik sosial yang terjadi dibeberapa wilayah tanah air dalam beberapa tahun

7 Syahrin Harahap, Teologi...,37. 
terakhir. Namun regulasi tersebut kemudian tidak bisa membendung derasnya komunikasi melalui sosial media. Sosial media yang menjadi media komunikasi masyarakat secara virtual pun tidak luput dari serangan konflik antar agama. Dalam hal ini segala bentuk hinaan, cacian bahkan komentar-komentar yang menyebabkan konflik di sosial media menjadi suatu hal yang perlu disikapi secara matang. Oleh karena itu komunikasi pembangunan agama di Indonesia belum mampu menyentuh eksistensi kehidupan keberagamaan masyarakat di sosial media. Hal ini terlihat sebagaimana gambar dibawah ini.

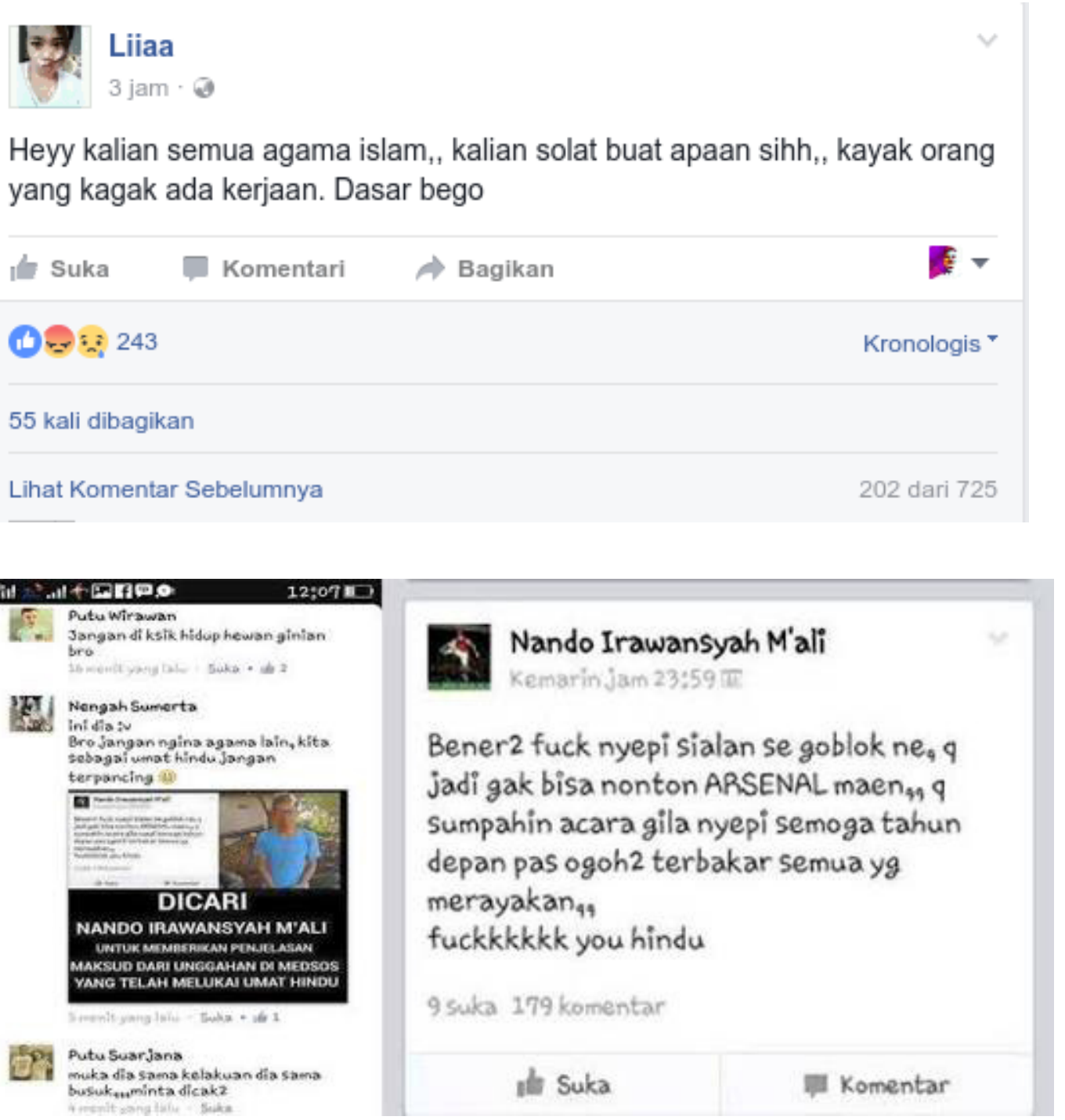


Dari gambar tersebut dapat dijelaskan bahwa konflik yang bernuasaagamadisosialmediasampai saat ini belum dapat diselesaikan secara baik. Konflik-konflik yang bermula dari permasalahan hinaan atau saling membalas komentar dapat berkembang menjadi konflik agama karena munculnya solidaritas antar kelompok yang berbeda pandangan keagamaan. Agama yang diharapkan menjadi pemersatu dalam masyarakat dikhawatirkan dapat menjadi pemicu perpecahan antar kelompok masyarakat.

Beberapa faktor penyebabnya adalah kurangnya pemahaman tentang esensi ajaran agama dari masyarakat. Apalagi ditambah dengan derasnya arus informasi di sosial media yang mewajibkan pengguna nya harus bisa membaca secara cerdas keabsahan berita tersebut. Literasi media dalam hal ini sangat dibutuhkan dalam pendekatan pembangunan agama. Tentunya pembangunan agama dimulai dari sikap terhadap pesan komunikasi yang diberikan oleh komunikator, isi pesan berupa ajaran agama, bentuk penyampaian pesan, pendekatan dan evaluasi terhadap pesan yang disampaikan.

Media Sosial Sebagai Media Pembangunan Agama

Sosial media sendiri menurut Van Dijk adalah platform media yang memfokuskan pada eksistesi pengguna yang memfasilitasi mereka dalam beraktivitas maupun berkolaborasi, sehingga sosial media sebagai fasilitator hubungan seseorang sekaligus sebagai sebuah ikatan secara virtual. ${ }^{8}$ Lebih lanjut Rulli Nasrullah menjelaskan beberapa karakteristik media sosial yaitu jaringan (network); informasi (information); arsip (archive); interaksi (interactivity); simulasi sosial (simulation of society) dan konten oleh pengguna (user generated content). Sedangkan untuk kategori sosial media, yaitu':

- Media jejaring sosial atau social networking, seperti facebook

- Jurnal online atau blog

- Jurnal online sederhana atau microblog, seperti twitter

- Media berbagi, seperti youtube, flicker, photobuckey, snapfish

- Penanda sosial seperti LintasMe

- Media konten bersama atau wiki Media sosial seperti Facebook, Twitter, Path, Youtube, WhatsApps, Instagramdenganfitur-fiturlike,sharefeed, tweet-retweet, upload-download, pathrepath,selfie-regram, post-repost telah menjadi aktivitas keseharian

8 Nasrullah, Rusli, Media Sosial Perspekstif Komunikasi, Budaya Dan Sosioteknologi,(Bandung: PT. Remaja Rosdakarya,2016). 11

9 Ibid., 14 
masyarakat Indonesia. Sayangnya, euphoria sosial mediamenunjukkan kondisi masyarakat yang mampu mengakses dan berbagi informasi secara fungsional, namun ada juga yang gagap teknologi, hanya mengikuti tren dan menjadi sasaran pembuat konflik.

Melihat kehadiran media sosial yang semakin massif, membuat literasi sosial media memiliki peran penting sebagai jawaban dari permasalahan diatas. Hal itu dikarenakan literasisosialmedia akan memberikan pemahaman kepada masyarakat untuk menggunakan media sosial secara proporsional. Pengguna yang literasinya cukup akan memiliki kesadaran, kendali, dan batasan yang jelas dalam menggunakan sosial media. Tidak sekadar mengikuti tren, yang penting update, bersikap reaksioner dan ikut dalam arena perdebatan yang tidak bermanfaat, bahkan seringkali andil menyebarluaskan informasi palsu (hoax). Akibatnya, informasisimpang siur bertebaran lewat pesan singkat, fotogambar (meme) dan termasuk kolom komentar.

Laporan penelitian Brendan Nyhan and Jason Reifler berjudul Misiformation and Fact-checking: Research Findings From Sosial Science menyimpulkan bahwa pengguna sosial media cenderung akan menolak berita dan informasi yang bertolak belakang dengan keyakinan, meskipun berita tersebut menunjukkan data dan fakta yang relatif lengkap.Sebaliknya, seseorang lebih suka mencari, membaca, dan menyebarkan berita yang sesuai dengan apa yang ia yakini meski berita itu belum jelas kebenarannya. Jika kemudian terbukti keliru dan menyadari sudah menyebarkan informasi salah, ia menganggapnya sebagai masalah kecil, bahkan tidak dianggap sebagai kesalahan dan ia akan menyalahkan media lain yang dikutip sebagai sumber tidak valid dan menyalahkan wartawan atau penulis aslinya. Walaupun internet adalah dunia tanpa batas, namun seperti halnya interaksi dalam dunia nyata, saat bersinggungan dengan orang lain maka sudah pasti ada aturan formal ataupun etika yang harus dipatuhi. Di dunia maya, seseorang tidak bisa bebas bertindak tanpa peduli kepentingan orang lain. Lalu bagaimana agama menyikapi fenomena ini?

Agama secara umum merupakan sebuah entitas yang di dalamnya berisi ajaran yang mempunyai fungsi untuk membangun dan menata kesadaran manusia mengenai hidup dan kehidupan di dunia ini. Artinya, semakin sadar manusia mengenai ajaran agama, maka semakin efektif peran dan fungsi agama dalam kehidupan manusia. 
Namun menurut Gidens posisi agama sekarang menjadi sangat dilematis karena saling bertabrakan dengan kemajuan ilmu pengetahuan dan teknologi, yang oleh manusia diposisikan sebagai Tuhan. Dengan kondisi demikian peran agama malah terpinggirkan karena manusia terjebak pada kehidupannya sendiri.

Sosial media sebagai salah satu sarana penyampai komunikasi pembangunan agama, sudah seharusnya menyelesaikan perbedaan agama melalui jalur komunikasi yang tidak mengedepankan emosi semata, namun juga intelektual. Oleh karena itu sosial media sebagai jalur komunikasi antar umat agama memiliki tujuan untuk mewujudkan kerukunan hidup di masyarakat dan membutuhkan perhatian serius dari semua pihak baik secara individual maupun secara kelompok bahkan kelembagaan, agar agama yang baik tidak hanya mampu meningkatkan kualitas keruunan beragama tetapi sekaligus mampu menciptakan iklim dikehidupan Indonesia yang bermoral.

Dari sosial media diharapkan meningkatkan kerjasama dalam menanggulangi masalah hubungan umat beragama terus berupaya meningkatkan kualitas kerukunan umat beragama, yang merupakan syarat mutlak bagi keberhasilan pembangunan.

Kerukunan

umat beragama merupakan suatu awal dari proses menuju ketidakrukunan berikutnya. Oleh karena itu kerukunan merupakan hal yang sangat penting sebelum umat beragama berbicara tentang kehidupan berbangsa.

Kualitas kerukunan umat beragama itu sendiri menjadi satu kunci sebelum bertindak lebih lanjut dan berkehidupan sebagai manusia yang beriman dan berbudi luhur. Dengan dilandasi kesadaran untuk rukun antar agama, maka dengan sendirinya kehidupan rakyat Indonesia akan tertata ulang dengan baik pula. ${ }^{10}$ Ada beberapa modelmodel komunikasi antar agama, salah satunya melalui perkataan dalam hal ini berupa dialog. Selain melalui dialog atau perkataan, dapat juga melalui sikap, yaitu

1. saling menghormati dan menghargai adalah dasar kerukunan

2. saling membantu dan memandang orang beda agama sebagai kawan

3. Kunjungan keagamanaan

4. Kerjasama sosial

5. bertetangga baik

10 Lubis, Ridwan, Meretas Wawasan dan Praksis Kerukunan Umat Beragama Di Indonesia Dalam Bingkai Masyarakat Kultural,(Jakarta: Puslitbang Kehidupan Beragama,2005). 123 
Sikap yang tulus tanpa kebohongan dalam kerukunan antar umat beragama baru dapat tercipta apabila didorong oleh dua hal. Pertama, tumbuh keyakinan bahwa kerukunan itu bukan hanya kepentinga politik melainkan sebagai keharusan menurut ajaran agama dan ketaatankepada tuhan. Kedua, tuntutan budaya dan adat istiadat.

Peningkatan kerjasama antar agama dapat menanggulangi masalah-masalah hubungan antar agama dan diharapkan akan terus berupaya meningkatan kerukunan umat beragama karena kerukunan merupakan syarat mutlak bagi keberhasilan pembangunan moral dan mental sekaligus akan mampu melakukan pembangunan nasional sebagaimana yang dicitakan. ${ }^{11}$

Ada beberapa komponen dalam komunikasi pembangunan yaitu pemerintah, lembaga-lembaga keagamaan dan masyarakat menjadi komponen untuk menghembuskan nafas kerukunan antar umat beragama. Komponen-komponen tersebut seharusnya memiliki komitmen nilai-nilai saling percaya dan saling pengertian diantara berbagai agama. Hal itu harus dilakukan untuk mengantisipasi dan menghalangi kekerasan yang mengatasnamakan agama yang

11 Ibid., 122. membawa hidup tidak aman dan damai di dunia ini. Penjelasan tugas sosial media dalam beberapa komponen tersebut adalah sebagai berikut:

\section{Pemerintah}

Pemerintah sebagai pemegang kebijakan nasional seharusnya memberikan sejumlah aturan perundangan yang bisa menjadi sarana pemersatu bangsa. Lebih khusus lagi dalam berkomunikasi melalui sosial media yang kaya akan perbedaan. Akan tetapi, pemerintah tentunya tidak bisa berjalan sendiri menciptakan dan menjaga kerukunan di sosial media ini, mengingat banyak hal menyangkut masalah keyakinan dan prinsipprinsip yang dianut masyarakat.

Kebijakan-kebijakan yang diambil pun seharusnya pemerintah memahamiagamadalampendekatan substantial, tidak hanya serimonial. Sehingga nantinya bentuk komunikasi yang dibangun melalui sosial media dengan jalur regulasi dapat diterima oleh masyarakat. Hal itu sejalan dengan penjelasan Tholkhah mengenai peranan pemerintah untuk mewujudkan kualitas kehidupan masyarakat. Pemerintah merupakan komponen strategis dalam hal ini, karena pemerintah memiliki kekuasaan dan tanggung jawab yang besar terhadap kesejahteraan masyarakat. Namun 
untuk mengimplementasikan kebijaksanaan tersebut diperlukan dukungan dari beberapa pihak, seperti organisasi agama dan dukungan dari sub struktur seperti para tokoh masyarakat dan para intelektualyang memiliki kepedulian terhadap pengembangan kehidupan masyarakat.

Selain itu juga, dalam membinaan kehidupan beragama, pemerintah tidak hanya menjamin kebebasan setiap penduduk untuk memeluk agama, tetapi juga mengkomunikasikan, menjamin, membina, mengembangkan, serta memberikan bimbingan dan pengarahan kepada masyarakat melalui sosial media agar kehidupan beragama tentram dan rukun satu sama lainnya.

\section{Masyarakat}

Manusia sebagai makhluk yang dinamis membawa masyarakat kian berubah seiring dengan semakin majunya pengetahuan dan teknologi. Pengetahuan yang semakin maju dan berkembang, menyebabkan masyarakat belum siap dengan perubahan yang ada bahkan terkadang lupa dengan agama $^{12}$. Salahsatu wujud untuk menanggulanginya adalah melalui pembangunan sarana komunikasi

12 Ismail, Faishal, Dinamika Kerukunan Antarumat Beragama,(Bandung:PT. Remaja Rosdakarya,2014).268. lintas agama secara massif dengan mengoptimalkan sosial media.

Dalam hal ini, tokoh agama sebagai elemen yang dipercaya oleh masyarakat, berperan sebagai fasilitator unuk mnenjembatani komunikasi dan kepentingan didalam kelompok masyarakat yang beragam. Hal itu untuk meminimalisir benturan antar kelompokyangberbeda dantentunya tokokagama memilikiposisistrategis untuk mengajak masyarakatnya hidup dalam kerukunan. Hal itu dikarenakan kelompok-kelompok masyarakat yang berbasis agama masih menaruh kecurigaan baik sesama kelompok agama apalagi di luar kelompok agama tertentu.

Tentunya yang pertama harus dilakukan adalah menganalisis fenomena sistem sosial keberagamaan. Fenomena ini penting untuk dianalisis karena akan menjadi langkah awal unyuk memulai membangun penguatan toleransiagama ${ }^{13}$.Setelah melakukan analisis keberagamaan dalam sistem sosial masyarakat, baru kemudian dapat menata proses komunikasi pembangunan agama untuk

13 Imam Tolkhah, Mewaspadai dan Mencegah Konflik Antar Umat Beragama, (Jakarta: Badan Litbang Agama dan Diklat Keagamaan Proyek Peningkatan Kerukunan Hidup Umat Beragama, 2001). 135 
melakukan penguatan toleransi agama di masyarakat.

Namunlangkah-langkahtersebut tentunya harus dilihat kembali kepada masyarakat yang mempunyai ruang publik berupa sosial media. Sosial media menjadi alat untuk mempertemukan setiap individu untuk melakukan interaksi, dengan interaksi tersebut masyarakat akan banyak mempelajari dari apa yang ia dapatkan dari lingkungannya, salah satunya mengenai sikap.

Oleh karena itu peran fasilitator agama menjadi sangat penting, ketika agama telah dianut oleh manusia, kemudian agama menjadi bagian dari kebudayaan masyarakat atau dalam hal ini berbentuk sikap, sehingga agama dan masyarakat serta kebudayaan mempunyai hubungan timbal balik yang saling pengaruh mempengaruhi. Tentu hal ini berkaitan langsung dengan sosial media yang sudah masuk kedalam bagian masyarakat.

Kesiapan masyarakat dalam mengahadapi sosial media tentunya berbeda-beda, begitupun juga dengan penerimaan masyarakat terhadap sosial media. Tak jarang masyarakat mudah terprovokasi oleh sosial media sehingga secara tidak langsung sosial media menjadi alat yang mempercepat konflik karena tidak adanya tabayyun dari masyarakat dan hilangnya sikap kritis dalam masyarakat. Oleh karena itu penting untuk menjaga masyarakat dari hal-hal yang dapat merusak tatanan kehidupan beragama khususnya di Indonesia, salahsatunya dengan memberikan bekal dan pemahaman mengenai sosial media.

3. Individu

Dalam level individu yang merupakan level terkecil dalam kehidupan telah mengalami ketidakpercayaan yang tinggi bahkan sudah sampai pada level kronis. Hal itu disebabkan karena tingkat informasi yang semakin banyak datang aau banjir informasi, menyebabkan pengguna sosial media menjadi samar dalam menerima informasi.

Ketidakpercayaan informasi ini dapat menjadi faktor dari dinamika sosial keagamaan yang dapat berujung pada konflik.

Oleh karena itu, untuk membangun semangat individu dalam berkomunikasi di sosial media dengan individu lainnya dalam bingkai pembangunan agama, yang harus dikembangkan adalah sikap saling memberi dan menerima. Sikap take and give itu kemudian menjadi sikaptenggangrasadanmenghormati terhadap nilai-nilai perbedaan. Tentu landasan utama untuk setiap individu dalam melakukan interaksinya yaitu kepercayaan satu sama lain. Kepercayaan itu diikat 
oleh prinsip saling pengertian (mutual understanding) sehingga melahirkan kerukunan.

Selain itu juga, upaya kerukunan umat beragama sangat diperlukan di sosial media dengan beberapa cara, yaitu: ${ }^{14}$

- Menghentikan bahasa hasutan

- Selalu mengkomunikasikan apapun yang terjadi (tabayyun)

- Melakukan komunikasi dengan bahasa damai

- Melakukan komunikasi dengan agama lain

\section{PENUTUP}

Sosial media hadir sebagai untuk memberikan kemudahan berkomunikasi antar manusia. Namun disisi lain, sosial media dapat menjadi penyebab konflik di masyarakat, baik konflik internal maupun eksternal keagamaan. Oleh karena itu, sudah seharusnya komunikasi pembangunan agama mencoba sarana untuk membangun kerukunan antar umat beragama melalui sosial media yang telah menjadi ruang publik masyarakat ini. Tentunya dengan adanya komunikasi pembangunan agama di sosial media melalui kelembagaan dan individu, diharapkan dapat ikut serta menjaga keutuhan NKRI dan mencegah konflik antar agama di Indonesia.

14 Ismail, Faishal, Dinamika Kerukunan Antarumat Beragama,(Bandung:PT. Remaja Rosdakarya,2014).127. 


\section{Daftar Pustaka}

Harahap, Syahrin, Pluralitas Agama: Kerukunan Dalam Keragaman,(Jakarta: Kompas, 2001)

Harahap, Syahrin, Teologi Kerukunan, (Jakarta: Prenada, 2011)

Hasan Sazali. Penguatan Toleransi Agama dalam Komunikasi Pembangunan Agama Studi Pemerintah Kota Bogor dan YogyakartaDisertasi, (Yogyakarta: Sekolah PascasarjanaUniversitasGadjah Mada Yogyakarta, 2015)

Imam Tolkhah, Mewaspadai dan Mencegah Konflik Antar Umat Beragama, (Jakarta, Badan Litbang Agama dan
Diklat Keagamaan Proyek Peningkatan Kerukunan Hidup Umat Beragama, 2001)

Ismail, Faishal, Dinamika Kerukunan Antarumat Beragama, (Bandung: PT. Remaja Rosdakarya, 2014)

Lubis, Ridwan, Meretas Wawasan dan Praksis Kerukunan Umat Beragama Di Indonesia Dalam Bingkai Masyarakat Kultural, (Jakarta: Puslitbang Kehidupan Beragama, 2005)

Mardikanto, Totok, Komunikasi Pembangunan, (Solo: UNS Presss, 2010)

Nasrullah, Rusli, Media sosial perspekstif komunikasi, budaya dan sosioteknologi, (Bandung: PT. Remaja Rosdakarya, 2016) 